\title{
Assessing drivers of rocky reef fish biomass density from the Southern California Bight
}

\author{
Daniel J. Pondella $\mathrm{II}^{1, *}$, Susan E. Piacenza ${ }^{1,2}$, Jeremy T. Claisse ${ }^{1,3}$, \\ Chelsea M. Williams ${ }^{1,3}$, Jonathan P. Williams ${ }^{1}$, Amanda J. Zellmer ${ }^{1}$, \\ Jennifer E. Caselle ${ }^{4}$ \\ ${ }^{1}$ Vantuna Research Group, Occidental College, Los Angeles, CA 90041, USA \\ ${ }^{2}$ Department of Biology, University of West Florida, Pensacola, FL 32514, USA \\ ${ }^{3}$ Department of Biological Sciences, California State Polytechnic University, Pomona, CA 91768, USA \\ ${ }^{4}$ Marine Science Institute, University of California, Santa Barbara, CA 93106, USA
}

\begin{abstract}
Biomass is often used as a metric for valuing and comparing ecosystems. However, many variables contribute to the amount of biomass an ecosystem can maintain; thus, it is necessary to evaluate the driving forces of patterns in biomass variation across sites. Here we utilized datasets associated with nearshore rocky reef fish biomass that span the Southern California Bight, using generalized least-squares modelling within the information-theoretic approach. Fish density, length, invertebrate density, algal density, and reef characteristics (relief and substrate type) were visually sampled at 89 sites, via SCUBA, with a random stratified sampling design using belt transects across depth strata in $<20 \mathrm{~m}$ depth. Fish data were converted to biomass using published length-weight relationships. In addition to our visual surveys, spatially resolved explanatory variables included sea surface temperature, sea surface chlorophyll $a$, maximum wave height, kelp biomass, fishery harvest intensity index, a new remote sensing method for calculating reef slope, and distance to the $200 \mathrm{~m}$ isobath, a novel characteristic. All models in the confidence model set $(\triangle \mathrm{AICc}<2)$ for total fish biomass included the variables sea surface temperature, distance to the $200 \mathrm{~m}$ isobath, sea surface chl $a$, slope, and the standard deviation of substrate and relief. Not all rocky reefs in the SCB equally support high densities of fish biomass, and our results suggest that an optimal combination of physical characteristics and forcing drive this variation. The novel variable, distance to the $200 \mathrm{~m}$ isobath, may be applicable for understanding fish biomass variation in marine ecosystems.
\end{abstract}

KEY WORDS: Spatial habitat patterns · Reef fish biomass density $\cdot$ Generalized least-squares modeling $\cdot$ Remote sensing $\cdot$ Southern California Bight

\section{INTRODUCTION}

Biomass is a fundamental metric that underlies ecosystem processes as it is a quantifiable and tractable metric of energy assimilation. For marine ecosystems, fish biomass has long been studied for its obvious socioeconomic implications and is the underlying metric of production (Clarke et al. 1946, Cushing 1975). Simply stated, ecosystems and associated

\footnotetext{
*Corresponding author: pondella@oxy.edu
}

features that maintain high biomass are valued above those that do not, and this metric is easily communicated and understood across all levels of society. Fish biomass is a primary parameter for analyzing trophic structure, predator-prey interactions, and associated cascades (Dulvy et al. 2004, Borer et al. 2005, DeLong et al. 2015, Selden et al. 2017). While the excessive removal of large predators in marine systems has severe ramifications (Jackson et al.

(C) The authors 2019. Open Access under Creative Commons by Attribution Licence. Use, distribution and reproduction are unrestricted. Authors and original publication must be credited. 
2001), how much biomass a marine ecosystem can support or ultimately produce and the ability to estimate it on small and large spatial scales has broad implications for the assessment goals of marine protected areas (MPAs), fishery management actions, infrastructure improvements, and restoration efforts (Graham 2004, Williams et al. 2015, Tam et al. 2017).

Top-down forces dramatically influence fish biomass. In all nearshore accessible ecosystems, extractive activities have impacted the standing stocks of marine fishes. The well-described consequences of overfishing can alter ecosystem structure, resilience, and performance (Tegner \& Dayton 2000, Steneck et al. 2002, Dulvy et al. 2004). While fishing mortality rates are quantifiable, the potential corresponding trophic cascades are more difficult to measure, and the associated potential negative feedbacks affecting ecosystem resilience, its correspondence to oceanographic condition, and these relationships with fish biomass need to be considered (Ling et al. 2009, Caselle et al. 2018a). A real challenge is understanding the importance of top-down cascades versus bottom-up forcing and associated production (Ban et al. 2016, Stamoulis et al. 2018). Elucidating the drivers that support the production and maintenance of fish biomass as a key feature of biodiversity on large spatial scales is critical for evaluating ecosystem function and performance (Fonseca et al. 2017). Thus, contextualizing the processes and determining mechanisms that support fish biomass is critical as we continue to manipulate and manage marine ecosystems.

Patterns of density and distribution of fishes are further complicated by temperature, on which fish are dependent as ectotherms. Changes in ocean temperature are ongoing, in some cases extreme, and predicted to continue (Perry et al. 2005, Oliver et al. 2018). Biogeographic provinces and the corresponding distribution of marine fishes are primarily explained by variation in temperature, especially in southern California, a transitional zone between the cold-temperate Oregonian and warm-temperate San Diegan faunas (Hubbs 1948, Pondella et al. 2005, Claisse et al. 2018b). Beyond being a driving factor in their distribution, temperature is also a key factor in the growth and development of marine fishes. In latitudinal studies, fishes tend to grow slower and live longer at colder clines, while populations in warmer areas exhibit faster growth rates and potentially earlier reproduction (Conover \& Present 1990, Behrens \& Lafferty 2007, Caselle et al. 2011). Growth trajectories are significant factors in understanding secondary production of biomass (Claisse et al. 2014, Pondella et al. 2015b) and can be influenced by the bottom-up forcing, which correlates with primary production and its associated flux through the trophic levels (Ware \& Thomson 2005). However, temperature is also correlated with nutrients, as cooler waters maintain higher nutrient levels and corresponding greater primary productivity (Kamykowski 1987, Konotchick et al. 2012). Thus, the interplay among these factors and the variety of species-specific trajectories can be dynamic, and the factors that support high levels of biomass are likely to be highly context-dependent.

Reef fishes associate with structure, either biotic or physical, and variation in habitat structure (e.g. relief, substrate, presence of macrophytes) can strongly influence distribution, richness, and diversity (Roberts \& Ormond 1987, Friedlander \& Parrish 1998, GarcíaCharton et al. 2004, Miller et al. 2018). For rocky reefs, the variation in habitat structure begins with the geological or biological features forming seascapes whose heterogeneity can vary on fine and coarse scales, setting the template for rocky reef performance (Parnell 2015, Wedding \& Yoklavich 2015). Physical forcing in the area further complicates this variation in topography (Williams et al. 2015). The orientation of a reef to the coastline and the corresponding variation in wave exposure, influence of currents, and especially degree of localized upwelling all factor into a dynamic and variable nearshore environment (Reed et al. 2011). In combination, these factors structure the biotic components in a reef system such as canopy-forming kelps, understory algae, and invertebrate cover, all of which, in turn, interact with each other (Reed \& Foster 1984, Graham 2004). These factors also contribute to creating a mosaic of available sub-habitat types and resources that marine fishes occupy differentially in time and space for shelter, feeding opportunities, and reproductive activities, and these requirements change with ontogeny (Anderson et al. 1989). As a resource, fishes optimize the utilization of nearshore reefs due to their structure and function, and this optimization of these factors is critical for their success (Roberts \& Ormond 1987, Connell \& Jones 1991, Hixon \& Beets 1993). Thus, we hypothesize that some reefs maintain higher fish biomass than others based upon a maximization or optimization of these factors.

To better understand these processes, we sampled fish biomass on nearshore rocky reefs across the Southern California Bight (SCB). This large and complex region, including 8 Channel Islands, has as much coastline $(\sim 1200 \mathrm{~km})$ as the rest of California, and its dynamic oceanography and high production make it an optimal natural experiment to explore the relationship among physical and biological processes 
(Emery 1960, Hickey 1993, Atwater 1998, Pondella et al. 2015a). Recent studies of secondary production in the SCB have elevated the region's importance, as the most productive studied marine habitats have been found here, yet secondary production rates and standing stocks exhibit significant spatial variation (Claisse et al. 2015, Pondella et al. 2015b). For nearshore rocky reefs, indicative of these cool nutrientrich currents is the hallmark giant kelp Macrocystis pyrifera, a well-documented habitat-forming species that is highly productive (Bell et al. 2015) and supports a diverse assemblage of fishes (Stephens et al. 2006). While the density, diversity, and distribution of kelp forest assemblages has been documented (Engle 1993, Pondella et al. 2005), studies of the distribution of fish biomass throughout this system have been limited (Caselle et al. 2011, 2015, Claisse et al. 2012, 2018).

The most readily available oceanographic metric for large spatial scales is sea surface temperature (SST), which varies spatially, seasonally, and annually in the $\mathrm{SCB}, \sim 6.8^{\circ} \mathrm{C}$ across latitudinal space. In addition to temperature, we also explored other spatially explicit physical variables that are potentially important to fish biomass distribution. The distance to the $200 \mathrm{~m}$ isobath was included as a proxy for the influence of cool nutrient-rich upwelling waters. Due to geologic processes, reefs in this region are proximate to the continental shelf, and this new metric was used to model an untested proxy of the dynamic relationship between localized upwelling and the cold, nutrient-rich waters it provides. Wave action, modeled as an average maximum wave height, was included as it is a significant factor in the distribution of giant kelp (Reed et al. 2011, Bell et al. 2015), and due to the amount of energy needed for fish to maintain position in high-energy environments, wave action may directly influence the distribution and biomass density of fishes or indirectly through its partial control of giant kelp. In turn, kelp can positively affect the abundance and diversity of fishes (Bodkin 1988, Graham 2004). Satellite-derived estimates of chlorophyll a (chl a) were also used as a proxy of bottom-up forcing (Ware \& Thomson 2005, Williams et al. 2015). Bottom-up processes and indicators of physical forcing are likely to be strong correlates of fish biomass density as primary and secondary production set the stage for localized processes.

The abiotic habitat structure of nearshore reefs in the SCB is variable, as these reefs range from cobble with little or no vertical relief to high-relief pinnacle structures, including a continuum of reef types (Pondella et al. 2015a). Reefs have been formed by vari- ous substrates (Emery 1960), and reef relief was previously demonstrated as a critical factor for fish biomass in the SCB with high-relief reefs outperforming low-relief reefs (Ambrose \& Swarbrick 1989). In addition to substrate and relief, reefs vary by slope as many island reefs created by uplift have dramatic slopes as opposed to, in general, mainland reefs that slope gradually (Ebeling et al. 1980). Mainland reefs are also influenced by sand due to the littoral cells that transport sediment along the coastline (Patsch \& Griggs 2006). This habitat variation between mainland and island reefs results in significant differences in the associated fish assemblages (Pondella \& Allen 2000). Thus, the geologic structure of rocky reefs should be a predictor of fish biomass density.

Biotic components of these nearshore reefs are known factors influencing fish biomass. The 2 major taxonomic groups that compose the major benthic habitats in this system are the canopy-forming kelps, giant kelp and bull kelp Nereocystis luetkeana, and red, purple and white urchins (Mesocentrotus franciscanus, Stongylocentrotus purpuratus and Lytechinus anamesus, respectively). High densities of urchins can effectively overgraze and eliminate understory and canopy-forming algae, resulting in urchin barrens, an alternative stable state to kelp forests (Harrold \& Reed 1985, Foster \& Schiel 2010, Ling et al. 2015). Understory algae also provide food resources and benthic structure for cover (Miller et al. 2018). There can be an inverse relationship among understory and canopy-forming kelps as they compete for space and light; canopy-forming kelps can shade understory algae (Reed \& Foster 1984, Kennelly 1989). Understanding the interplay among these taxonomic groups and fish biomass density is challenging because (1) not all rocky reefs support canopy-forming kelps, (2) the relationship between algal biomass and fish biomass is not direct (as most fishes are not obligate herbivores), and (3) while some fishes eat urchins, urchins in barrens are not preferred prey items likely due to their reduced caloric value (Eurich et al. 2014). Disentangling the interactions among these biotic characteristics and reef fish production has not been attempted in this ecosystem.

Extractive activities affect fish abundance, diversity, and biomass on a global scale (Worm et al. 2006). In southern California, commercial and recreational fishers access nearshore resources at different spatial scales (Zellmer et al. 2018). In general, recreational fishers target finfish with greater pressure on reefs on the mainland and islands close to harbors (e.g. 
Santa Catalina and Anacapa; see Fig. 1), whereas commercial fishers target primarily invertebrates with greater pressure in offshore habitats (Zellmer et al. 2018). Fishing pressure, while present on all reefs with the exception of well-enforced marine reserves, is heterogeneous throughout the SCB with respect to taxa, reef size, and access (Zellmer et al. 2018).

\section{MATERIALS AND METHODS}

We conducted SCUBA surveys using a quantitative standardized monitoring protocol (Hamilton et al. 2010, Claisse et al. 2012). Surveys were conducted during the summer through fall in 2004, 2008, 2011, and 2012. At each site, $30 \times 2 \mathrm{~m}$ belt transects were surveyed using a random stratified sampling design, within 4 benthic and 4 midwater fish transects located in 3 targeted depth zones $(5,10$, and $15 \mathrm{~m}$; $\pm 2.5 \mathrm{~m}$ ). Within a depth zone if kelp canopy was present, 4 additional transects were conducted in the canopy. In shallow-water sites ( $<5 \mathrm{~m}$ depth), midwater surveys were not included because they overlapped with the canopy and bottom transects. A total of 4575 transects were completed across 89 sites throughout the SCB (south of Pt. Conception to the USA-Mexico border; see Fig. 1). Not every site was sampled in each of the 4 years, but only sites with $\geq 2 \mathrm{yr}$ of sampling were included. Coastal pelagic or pelagic taxa (Allen \& Pondella 2006), infrequently observed cryptic species, and juveniles were removed from the dataset (Anderson et al. 1989, Stephens et al. 2006).

During the SCUBA surveys, divers visually assess abundance and total length of fish observed along the transects. Using species-specific morphometric relationships, total fish biomass density is calculated as follows:

$$
B_{f, Y}=\sum_{j=1}^{n} \sum_{i=1}^{m} N_{i, j, f, Y} W_{i, j}
$$

where $N_{i, j, f, y}$ is the density of size class $i$ of species $j$ at each site $f$ in each year surveyed $y$ summed across all size classes $m$ and species $n$ observed, and weight $w_{i, j}(\mathrm{~g})$ was the average weight at length. Mean weight at length was calculated as follows:

$$
w_{i, j}=a_{j} L_{i, j} b_{j}
$$

where $L_{i, j}$ is length $(\mathrm{cm})$, and $a$ and $b$ are speciesspecific curve parameters (Miller et al. 2008, Williams et al. 2013, Claisse et al. 2014). In order to characterize patterns of fish biomass for each site, the average biomass density for each sampling year was calculated, and then the grand mean across all sampling years was calculated. Similar calculations were made for the 6 most abundant species in the dataset as well as 2 cold-water rockfish, which were abundant in the northern SCB. In the individual species models, sites where the taxon was not observed were excluded from the analysis because we could not separate effects from our explanatory variables with biogeographic species distribution patterns.

We collated a variety of environmental and socioeconomic variables, which would likely have an influence on fish biomass (Table 1). Some variables were collected in situ during the SCUBA surveys, while others were synthesized from remote sensing data using geographic information systems (GIS). During the SCUBA surveys, divers collected information on kelp understory species density $\left(\mathrm{N} \mathrm{m}^{-2}\right)$ and urchin density $\left(\mathrm{N} \mathrm{m}^{-2}\right)$. We included the density of giant kelp stipes to holdfasts ( $\mathrm{N}$ stipes holdfast ${ }^{-1} \mathrm{~m}^{-2}$ ), as we have observed that fishes tend to avoid high-density stipe stands, especially of newly forming beds, with little void space as opposed to mature kelp forests. Divers also collected data on vertical relief and benthic habitat substrate, and we used these data to create 2 indices to characterize these reef attributes. In each transect, divers characterized $1 \mathrm{~m}$ segments of a transect as 1 of 3 types of relief: <1.0, $1-2$, and $>2 \mathrm{~m}$. We calculated the transect-level relief index (RI) at site $f$ and transect $l$ as follows:

$$
\mathrm{RI}_{f, l}=P_{f, l, k} \cdot R_{\mathrm{k}}
$$

where $P$ is the proportion of cover (range: $0-1$ ) of relief type $k$, and $R$ is the relief score for relief type $k$. The substrate index was calculated similarly to the RI, but the substrate categories and scores were as follows: (1) sand, (2) 'cobble,' up to $10 \mathrm{~cm}$ diameter rock, (3) 'boulder,' 0.1-1.0 m diameter rock, and (4) 'bedrock,' $>1 \mathrm{~m}$ diameter rock. In addition to quantifying differences in small-scale topography, substrate also corresponds with the probability a rock will be moved or flipped over during wave events. We calculated the transect-level substrate index (SI) at site $f$ and transect $l$ as follows:

$$
\mathrm{SI}_{f, l}=P_{f, l, k} \cdot S_{k}
$$

where $P$ was the proportion of cover (range: $0-1$ ) of substrate type $k$, and $S$ was the substrate score for substrate type $k$. For both the RI and SI, the mean and standard deviation across transects was calculated for each site during each of the sample years, and the grand mean and standard deviation were calculated across all of these sampling year means. The standard deviation of the RI and SI were intended to 
quantify heterogeneity in these habitat characteristics that may ultimately influence fish biomass.

We accessed a variety of remotely sensed variables to characterize average environmental conditions for each site across the SCB. We collated data on MODIS-derived sea surface temperature $\left(\mathrm{SST}^{\circ}{ }^{\circ} \mathrm{C}\right)$ and sea surface chl a (CHL; $\mathrm{mg} \mathrm{m}^{-3}$ ) from University of California San Diego, Scripps Institution of Oceanography Photobiology Group (http://spg.ucsd.edu; Table 1). The raw data consists of $15 \mathrm{~d}$ averages for both SST and CHL throughout the California Current Large Marine Ecosystem. For each sampling year (i.e. 2004, 2008, 2011, and 2012) at each site, we calculated the mean of the preceding $5 \mathrm{yr}$ (inclusive of the sampling year) to quantify the average SST or CHL conditions over a recent, but moderately extended period that would potentially influence the observed biomass during a sampling year. We then calculated a grand mean for each site averaging these 5 yr mean values as not every site was sampled in each of the 4 years, and the focus of our study was on spatial rather than temporal variation of fish biomass across this region. Five years was chosen as the appropriate context for the recent life history of most fishes. Data from the Coastal Data Information Program's (CDIP; http://cdip.ucsd.edu/) nowcast wavepropagation model were used to assess spatial variations in wave height $\left(H_{\mathrm{si}}\right.$ Bell et al. 2015]. For each site to model the potential energy associated with living in the current wave regime, we calculated the mean of maximum wave heights for monthly periods for the 2 yr previous to the sampling year (inclusive of the sampling year) and then calculated the grand mean for all of the sampling years. Remotely sensed kelp biomass was measured using LANDSAT imagery (wet $\mathrm{kg}$ canopy $900 \mathrm{~m}^{2}$ pixel), and data were accessed from the Santa Barbara Coastal Long-term Ecological Research (SBC-LTER) program (Cavanaugh et al. 2011, Bell et al. 2015, 2017). Because kelp canopy typically varies on an annual timeframe, we averaged the 2 yr previous and inclusive of sampling year and calculated the grand mean for all sampling years for each site. Reef slope (degrees) was calculated from a bathymetry digital elevation model from the California Department of Fish and Wildlife (CDFW) Bathymetry Project (2nd edition). Raw data were projected to WGS 1984 UTM Zone 11 to minimize distortion. Using ArcMap 10.3 (ESRI 2014), the slope of each site is calculated as the maximum rate of change in elevation from seafloor between the cell (cell size $200 \mathrm{~m}^{2}$ ) and its nearest neighbors. One site off San Nicolas Island, Begg Rock, a steep rock pinnacle formation, was inaccurately smoothed out in the bathymetry DEM. Thus, we used the value from the site with the steepest slope, Blue Cavern off Santa Catalina Island, so that Begg Rock was more accurately characterized as a site with a very steep slope. The distance from each site to the shelf break, defined as the $200 \mathrm{~m}$ isobath, was calculated in ArcMap, the Contour tool creates a line feature class of contours (isolines) from a raster surface, and the Euclidean distance (m) from the cell to the nearest $200 \mathrm{~m}$ isobath was used as an estimate of localized upwelling (Sea Around Us Project 2012).

The analysis of the biological and physical characteristics of these reefs was augmented with an estimate of human extracted biomass calculated with a harvest intensity index (HII). The HII is a measure of the metric tons of reef fish and invertebrates captured in the commercial and recreational fisheries scaled across the total reef area in a fishing block (cell size: $100 \mathrm{~km}^{2}$ ) averaged across the $10 \mathrm{yr}$ preceding the field surveys, inclusive of the survey year (metric tons [MT] $\mathrm{yr}^{-1} \mathrm{~km}^{-2}$ ) to yield a measure of harvest intensity relevant to the year each a site was surveyed. This longer time frame was used to allow for potential top-down effects to cycle through the system. Complete details on how the HII is calculated are provided by Zellmer et al. (2018). As the database was only available through 2009, surveys that were completed in 2011 and 2012 only contain 8 or 9 yr of data, respectively, versus the earlier surveys, which contain data for the mean of the full $10 \mathrm{yr}$ preceding the SCUBA surveys. We then calculated a HII grand mean for each site as the average of the means calculated for each sample occasion. Sites that were in MPAs throughout the study duration were given an HII value of 0 . Prior to statistical analysis, we $\log _{10^{-}}$ transformed HII, which successfully disabled outliers from unduly influencing any potential relationships with HII and biomass density.

We first tested for potential collinearity among explanatory variables using Pearson correlations and variance inflation factors (VIF). Only the Mean Relief Index and Standard Deviation of Relief Index had a correlation above our a priori threshold of $0.7\left(\mathrm{r}^{2}=\right.$ 0.81; Zuur et al. 2017). We calculated the VIFs of variables included in the top-ranked model for each response variable. All explanatory variables were standardized to be centered at 0 by taking the value minus the mean divided by the standard deviation using the scale function in R. Initial exploratory analyses of the global model of all fishes suggested a degree of spatial autocorrelation in total fish biomass (Moran's I $=0.120, p=0.00206$ ). The response variable Mean Biomass Density did not conform to the 
Table 1. Summary of primary reef-scale explanatory variables. NA: not applicable; CDFW: California Department of Fish and Wildlife; UCSB: University of California, Santa Barbara

\begin{tabular}{|c|c|c|c|c|c|c|}
\hline \multirow[t]{2}{*}{ Variable name } & \multirow[t]{2}{*}{ Abbrev. } & \multirow[t]{2}{*}{ Description } & \multirow[t]{2}{*}{ Unit } & \multicolumn{2}{|c|}{ Resolution } & \multirow[t]{2}{*}{ Source } \\
\hline & & & & Spatial & Temporal & \\
\hline $\begin{array}{l}\text { Distance to Shelf } \\
\text { Break }\end{array}$ & DIST & $\begin{array}{l}\text { Distance to shelf } \\
\text { break ( } 200 \mathrm{~m} \text { isobath) }\end{array}$ & $\mathrm{m}$ & $200 \mathrm{~m}^{2}$ & NA & $\begin{array}{l}200 \mathrm{~m}^{2} \text { digital eleva- } \\
\text { tion model; CDFW }\end{array}$ \\
\hline Reef Slope & SLOP & $\begin{array}{l}\text { Steepest downhill } \\
\text { descent in cell }\end{array}$ & degrees & $200 \mathrm{~m}^{2}$ & NA & $\begin{array}{l}200 \mathrm{~m}^{2} \text { digital eleva- } \\
\text { tion model; CDFW }\end{array}$ \\
\hline $\begin{array}{l}\text { Maximum Wave } \\
\text { Height }\end{array}$ & WHM & $\begin{array}{l}\text { Average maximum } \\
\text { wave height }\end{array}$ & $\mathrm{m}$ & $\begin{array}{l}\text { Data from buoys } \\
\text { located closest } \\
\text { to Site }\end{array}$ & $\begin{array}{l}\text { Mean of } \\
\text { preceding } \\
2 \mathrm{yr}\end{array}$ & T. Bell / UCSB \\
\hline $\begin{array}{l}\text { Kelp Canopy } \\
\text { Biomass }\end{array}$ & $\mathrm{KBIO}$ & $\begin{array}{l}\text { Wet kg canopy } \\
\text { per } 900 \mathrm{~m}^{2} \text { pixel }\end{array}$ & $\mathrm{kg} \mathrm{m}^{-2}$ & $\begin{array}{l}900 \mathrm{~m}^{2} \text { radius } \\
\text { around Site }\end{array}$ & $\begin{array}{l}\text { Mean of } \\
\text { preceding } 2 \mathrm{yr}\end{array}$ & T. Bell / UCSB \\
\hline $\begin{array}{l}\text { Sea Surface } \\
\text { Chlorophyll a }\end{array}$ & $\mathrm{CHL}$ & $\begin{array}{l}\text { Mean sea surface } \\
\text { chlorophyll a }\end{array}$ & $\mathrm{mg} \mathrm{m}^{-3}$ & $\begin{array}{l}1 \mathrm{~km}^{2}-\text { mean } \\
\text { of } 4 \text { grid cells } \\
\text { near Site }\end{array}$ & $\begin{array}{l}\text { Mean of across } \\
\text { preceding } 5 \mathrm{yr}\end{array}$ & $\begin{array}{l}\text { Scripps Photobiology } \\
\text { Group }\end{array}$ \\
\hline $\begin{array}{l}\text { Sea Surface } \\
\text { Temperature }\end{array}$ & SST & $\begin{array}{l}\text { Mean sea } \\
\text { surface temperature }\end{array}$ & ${ }^{\circ} \mathrm{C}$ & $\begin{array}{l}1 \mathrm{~km}^{2}-\text { mean } \\
\text { of } 4 \text { grid cells } \\
\text { near Site }\end{array}$ & $\begin{array}{l}\text { Mean of across } \\
\text { preceding } 5 \mathrm{yr}\end{array}$ & $\begin{array}{l}\text { Scripps Photobiology } \\
\text { Group }\end{array}$ \\
\hline $\begin{array}{l}\text { Harvest Intensity } \\
\text { Index }\end{array}$ & HII & $\begin{array}{l}\text { HII for commercial } \\
\text { and recreational } \\
\text { fishing combined }\end{array}$ & MT $\mathrm{yr}^{-1} \mathrm{~km}^{-2}$ & $100 \mathrm{~km}^{2}$ & $\begin{array}{l}\text { Mean of } \\
\text { preceding } 10 \mathrm{yr}\end{array}$ & Zellmer et al. (2018) \\
\hline Urchin Density & UD & $\begin{array}{l}\text { Urchin species } \\
\text { density }\end{array}$ & no. $\mathrm{m}^{-2}$ & $\begin{array}{l}\text { In situ } \\
\text { collection }\end{array}$ & Day of survey & SCUBA in situ \\
\hline $\begin{array}{l}\text { Giant Kelp } \\
\text { Stipes Ind. }^{-1}\end{array}$ & STIP & $\begin{array}{l}\text { Number of stipes } \\
\text { per individual kelp }\end{array}$ & no. $\mathrm{m}^{-2}$ & $\begin{array}{l}\text { In situ } \\
\text { collection }\end{array}$ & Day of survey & SCUBA in situ \\
\hline $\begin{array}{l}\text { Kelp Understory } \\
\text { Spp. Density }\end{array}$ & KUSP & $\begin{array}{l}\text { Kelp understory } \\
\text { species density }\end{array}$ & no. $\mathrm{m}^{-2}$ & $\begin{array}{l}\text { In situ } \\
\text { collection }\end{array}$ & Day of survey & SCUBA in situ \\
\hline $\begin{array}{l}\text { Mean Relief } \\
\text { Index }\end{array}$ & MRI & $\begin{array}{l}\text { Quantification of } \\
\text { relief types } \\
(0-1,1-2 \text {, and }>2 \mathrm{~m})\end{array}$ & & $\begin{array}{l}\text { In situ } \\
\text { collection }\end{array}$ & Day of survey & SCUBA in situ \\
\hline $\begin{array}{l}\text { Relief Index } \\
\text { Standard Deviation }\end{array}$ & RISD & $\begin{array}{l}\text { Variability of relief } \\
\text { types }\end{array}$ & & $\begin{array}{l}\text { In situ } \\
\text { collection }\end{array}$ & Day of survey & SCUBA in situ \\
\hline $\begin{array}{l}\text { Mean Substrate } \\
\text { Index }\end{array}$ & MSI & $\begin{array}{l}\text { Quantification of sub- } \\
\text { strate types (sand, cob } \\
\text { boulders, and bedrock }\end{array}$ & ble, & $\begin{array}{l}\text { In situ } \\
\text { collection }\end{array}$ & Day of survey & SCUBA in situ \\
\hline $\begin{array}{l}\text { Substrate Index } \\
\text { Standard Deviation }\end{array}$ & $\mathrm{n}$ SISD & $\begin{array}{l}\text { Variability of substrate } \\
\text { types }\end{array}$ & & $\begin{array}{l}\text { In situ } \\
\text { collection }\end{array}$ & Day of survey & SCUBA in situ \\
\hline
\end{tabular}

assumptions of a normal distribution and displayed heterogeneity in variance. Therefore, we chose to use a generalized least-squares modeling approach (GLS) to model the relationships between fish biomass density (site level grand means across the years each site was sampled) and the site means (often grand means) of explanatory variables (Table 1). GLS is consistently superior to other modeling approaches when spatial autocorrelation is present (Begueria \& Pueyo 2009, Zuur et al. 2017). Our model framework accounted for spatial autocorrelation (with Gaussian correlation structure) and heterogeneity in the variance structure. Additionally, the biomass densities for the single species analyses were $\log (x+1)$ transformed because values had positively skewed distributions with many near-zero values and $\geq 1$ very high biomass values, and an extremely high kelp bass Paralabrax clathratus biomass outlier from 1 site (Lover's Cove, Santa Catalina Island; an MPA throughout the study) was removed from the analysis after assessment of model residuals revealed it as a very high leverage and influential point that was likely resulting in spurious relationships.

We used restricted maximum likelihood estimation (REML) to fit models containing the full set of explanatory variables (Table 1) to evaluate several pos- 
sible variance and correlation structures for total fish biomass density and species-specific biomass density. Akaike's information criterion correction for small sample sizes (AICc) was used to select the optimal variance structure that resulted in homogeneity of variance structures (Zuur et al. 2017). We also used the information-theoretic approach for model selection, based on AICc (Burnham \& Anderson 2002, Johnson \& Omland 2004), with the dredge function in the R package MuMIn. Collinear variables (Pearson correlation $>0.7)$ were not allowed in the same model (e.g. Mean Relief Index and Standard Deviation of Relief Index), and $\leq 7$ explanatory variables were allowed in the candidate models to avoid overfitting (Zuur et al. 2017). We tested the VIF of variables in the top-ranked model for each of the fish biomass response variables, and all were less than the $a$ priori cut-off of 10 (Zuur et al. 2017). Models with $\Delta \mathrm{AICc}<2$ were retained. We examined the relative importance of each variable included in the confidence model set, which gives the sum total weight of all models containing a particular variable (Burnham and Anderson 2002). High values of relative importance result from variables occurring in a large proportion of highly ranked models. We also examined models within the confidence set for uninformative parameters, where the model was within $\Delta \mathrm{AICc}<2$, but the maximized log-likelihood was essentially the same as the best model (Arnold, 2010; Burnham \& Anderson 2002). We relied on the relative importance metric to evaluate the contribution of each parameter in estimating fish biomass density and discarded models that a priori were included in the confidence set but were not truly competitive with the best model (Arnold 2010). Residuals from the topranked models for total fish biomass and each focal species were used to as an additional method to visually assess model assumptions and fit (see Fig. S1). All analyses were performed in R v.3.5.2 (R Development Core Team 2018).

\section{RESULTS}

We saw very large variation in mean $( \pm 1 \mathrm{SE})$ biomass density of all fishes combined, ranging from $8.0 \pm 1.7 \mathrm{~g} \mathrm{~m}^{-2}$ to $219.5 \pm 3.5 \mathrm{~g} \mathrm{~m}^{-2}$ (Fig. 1, see Table S1 in the Supplement at www. int-res.com/articles/suppl/m628p125_supp.pdf). The average density across all sites in the SCB was $71.1 \mathrm{~g} \mathrm{~m}^{-2}$. In general, mainland sites tended to have lower biomass density while island sites had higher values, but some exceptions occurred, e.g. low biomass on the north shore of Santa Rosa Island and high biomass at sites in the northern Malibu area and Crystal Cove along Newport Beach. For total biomass of all fishes combined, all models in the confidence model set $(\triangle \mathrm{AICC}<2)$ included the variables distance to $200 \mathrm{~m}$ isobath (DIST), sea surface chl a (CHL), sea surface temperature (SST), reef slope (SLOP), relief index standard deviation (RISD), and substrate index standard deviation (SISD), and the relative importance (REI) for each of these variables was 1.0 (Figs. 2-4, Tables S2 \& S3). Total fish biomass was positively correlated with SLOP, RISD, and CHL but negatively correlated with SST and DIST, and while SISD was included in the confidence model set, its $95 \%$ confidence interval included zero and therefore the direction of the relationship cannot be determined as significantly different from 0 (Fig. 4).

Biomass density varied appreciably across all the focal species in this study (Fig. 5, Table S1). When the predictor variables were examined across the topranked models for the 8 species and all fishes combined, patterns in their relationships emerged (Fig. 4). For the predictors that occurred most frequently, the directionality of the relationship was generally conserved across taxa. SST was important (i.e. high REI) in the most cases (5 of 8: all fishes, blue rockfish Sebastes mystinus, garibaldi Hypsypops rubicundus, kelp rockfish $S$. atrovirens and senorita Oxyjulis californica; Table S2), and had significant negative relationships to fish biomass density, with a significant positive relationship with garibaldi biomass being the exception (Fig. 4). RISD was important in half of the cases (4 of 8: all fishes, garibaldi, opaleye Girella

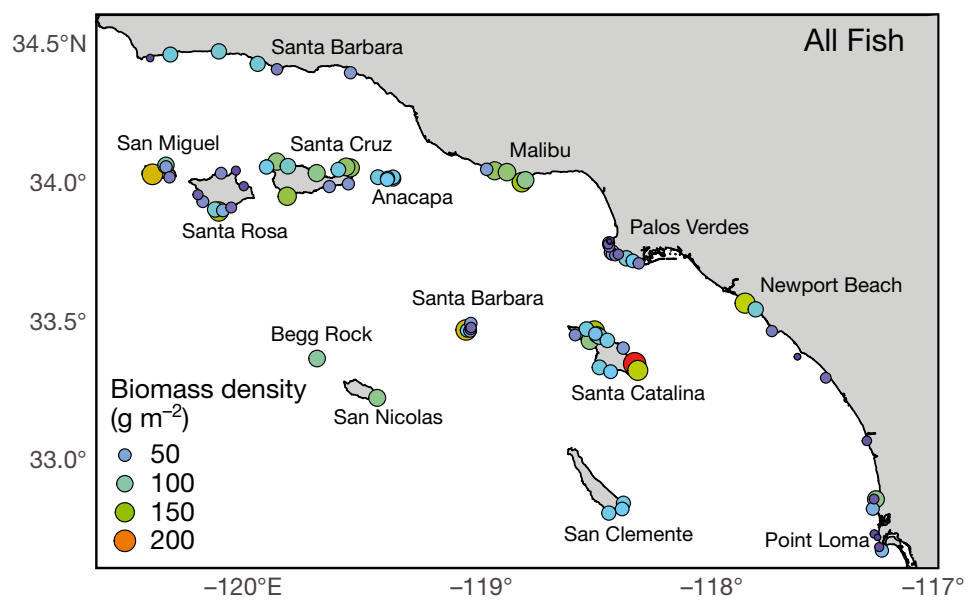

Fig. 1. Heat map of biomass density $\left(\mathrm{g} \mathrm{m}^{-2}\right)$ of all fish species combined at the study reef sites in the SCB 

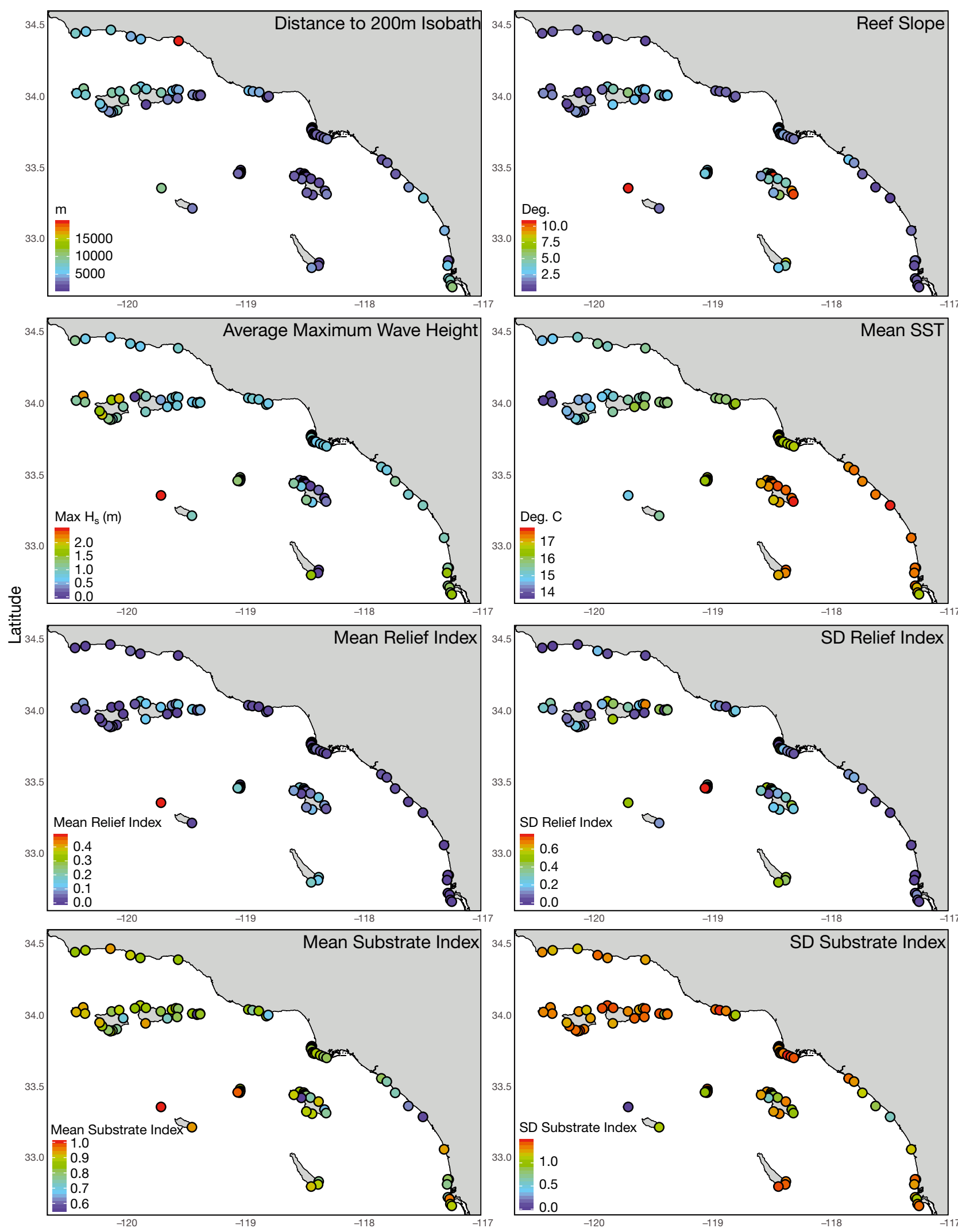

Fig. 2. Heat map of spatial variation in abiotic predictor variables across reef study sites in the SCB 


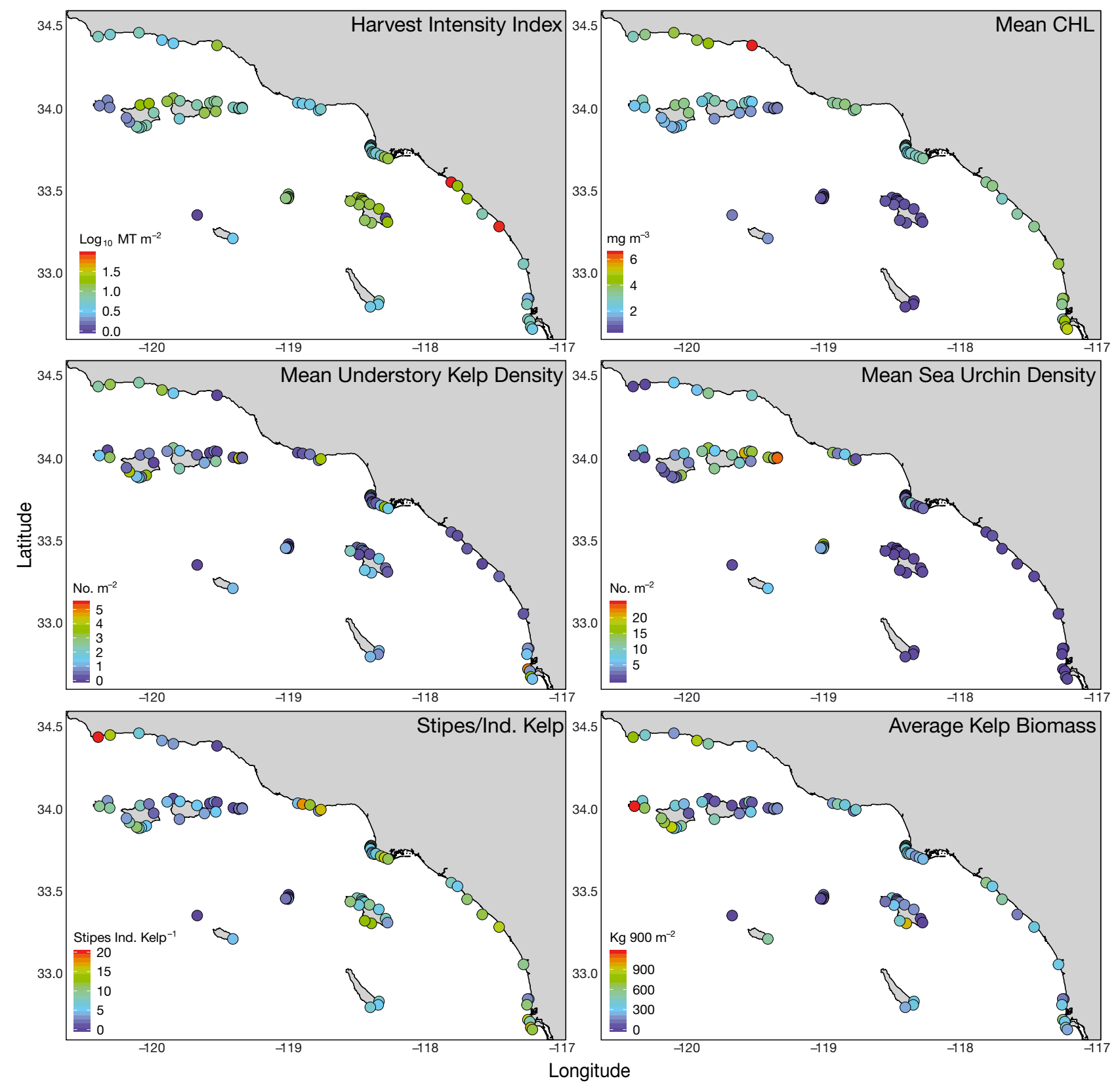

Fig. 3. Heat map of spatial variation in biotic predictor variables across reef study sites in the SCB

nigricans, and California sheephead Semicossyphus pulcher; Table S2) and with significant positive relationships to fish biomass density (Fig. 4). Reef slope had significant positive relationships with fish biomass density in the 3 cases where it was important (all fishes, blacksmith Chromis punctipinnis, and garibaldi; Fig. 4, Table S2). However, while CHL had a significant positive relationship with total fish biomass, it had a significant negative relationship with opaleye biomass, the only other species where it was in a top-ranked model (Fig. 4). Three additional vari- ables that were not important in the total fish biomass models were significant in the top-ranked models of individual species: mean relief index (MRI; positive relationship with blacksmith), urchin density (UD; positive relationship with blacksmith and garibaldi), and maximum wave height (WHM; positive relationship with blue rockfish). Some of the fish species had relatively low support for the environmental explanatory variables in the model confidence set. For example, the single explanatory variable included in the top-ranked model for kelp bass Paralabrax 


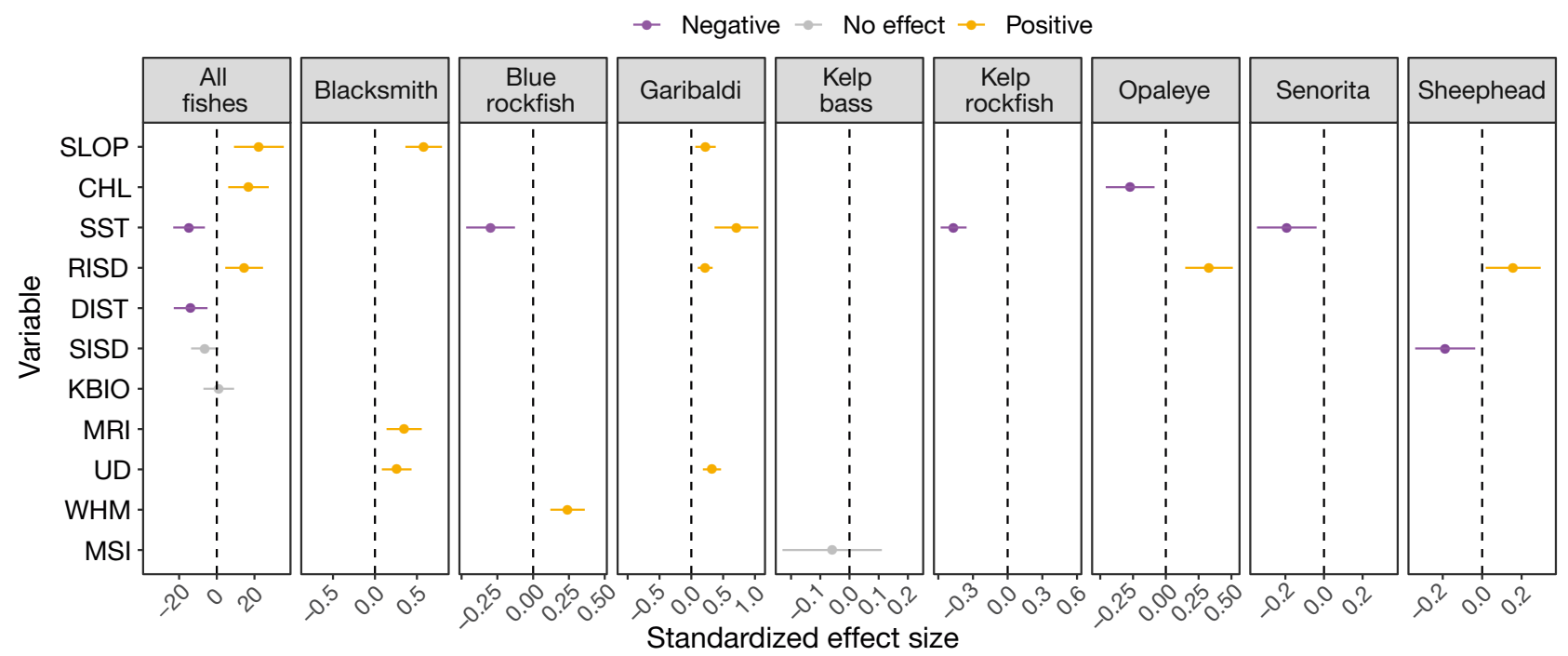

Fig. 4. Influence of predictor variables of reef sites (abbreviations defined in Table 1) on the response variable, fish biomass density, included in the top-ranked generalized least squares models for all fishes (untransformed) and each of the individual species [log $(x+1)$ transformed]. Parameter estimates are the mean estimate and $95 \%$ confidence interval (95\% CI). Purple (estimate $<0$ ) and yellow (estimate $>0$ ) slope estimates have $95 \%$ CIs that do not include 0, while gray slope estimates have $95 \%$ CIs that cross 0 and are not considered significant. Macrocystis stipes/kelp (STIP), kelp understory spp. density (KUSP) and harvest intensity index (HII) were included in the analysis but were not in the top-ranked models and therefore not presented here. Also note that the generalized least-squares modeling approach used in this study included a spatial autocorrelation structure that often accounted for a large proportion of the variation in fish biomass, such that the top models often had fewer predictor variables in them than one might expect

clathratus had a confidence interval that included zero. However, this suggests that including the spatial autocorrelation structure in the generalized leastsquares modeling approach accounted for a large proportion of the variation in fish biomass, as the evidence ratio for a simple model that accounts for the spatial autocorrelation versus one that ignored it was 46.6. This further supports that there is a high degree of spatial patterning of fish biomass density across the SCB.

\section{DISCUSSION}

Understanding the drivers of biomass variation across ecosystems is important for contextualizing these processes over a variety of spatial scales. We were able to identify a set of physical and biological explanatory variables that were significantly related to patterns of fish biomass density across rocky reef ecosystems in the SCB. The direction of the relationship between biomass density and some of the predictors was conserved across species (especially those that occurred more frequently in the top-ranked models). For example, SST was negatively correlated with biomass density in total fish biomass and all species, except garibaldi Hypsypops rubicundus, where it was included in the top-ranked model. This is particularly interesting because the SCB is in a convergence zone of the southward-flowing California Current, which bathes the northern Channel Islands in cold water, and the warm northward-flowing California Countercurrent, which carries warmer water from northern Mexico (Hickey 1992). As such, many of the most abundant species have either tropical or temperate lineages. For example, all 6 of the most abundant species in the dataset have family lineages in tropical waters, while the less widely distributed rockfishes Sebastes sp. are found almost exclusively in sub-arctic to temperate waters. So, it may appear counterintuitive that reefs with cooler mean SST tended to support the greatest fish biomass density overall. Colder water is associated with the influence of the California Current and local upwelling, the 2 critical physical forcing processes associated with primary production in the SCB. Similarly, fish biomass density tends to be greater at reefs situated closer to the continental shelf break (negative relationship with distance to $200 \mathrm{~m}$ isobath, DIST). The shelf break is dynamic and influenced by upwelling, currents, tides and internal waves (Vanney \& Stanley 1983). The distance to the shelf break as a predictor variable may also represent a composite of other environmental conditions below the thermocline, rather 

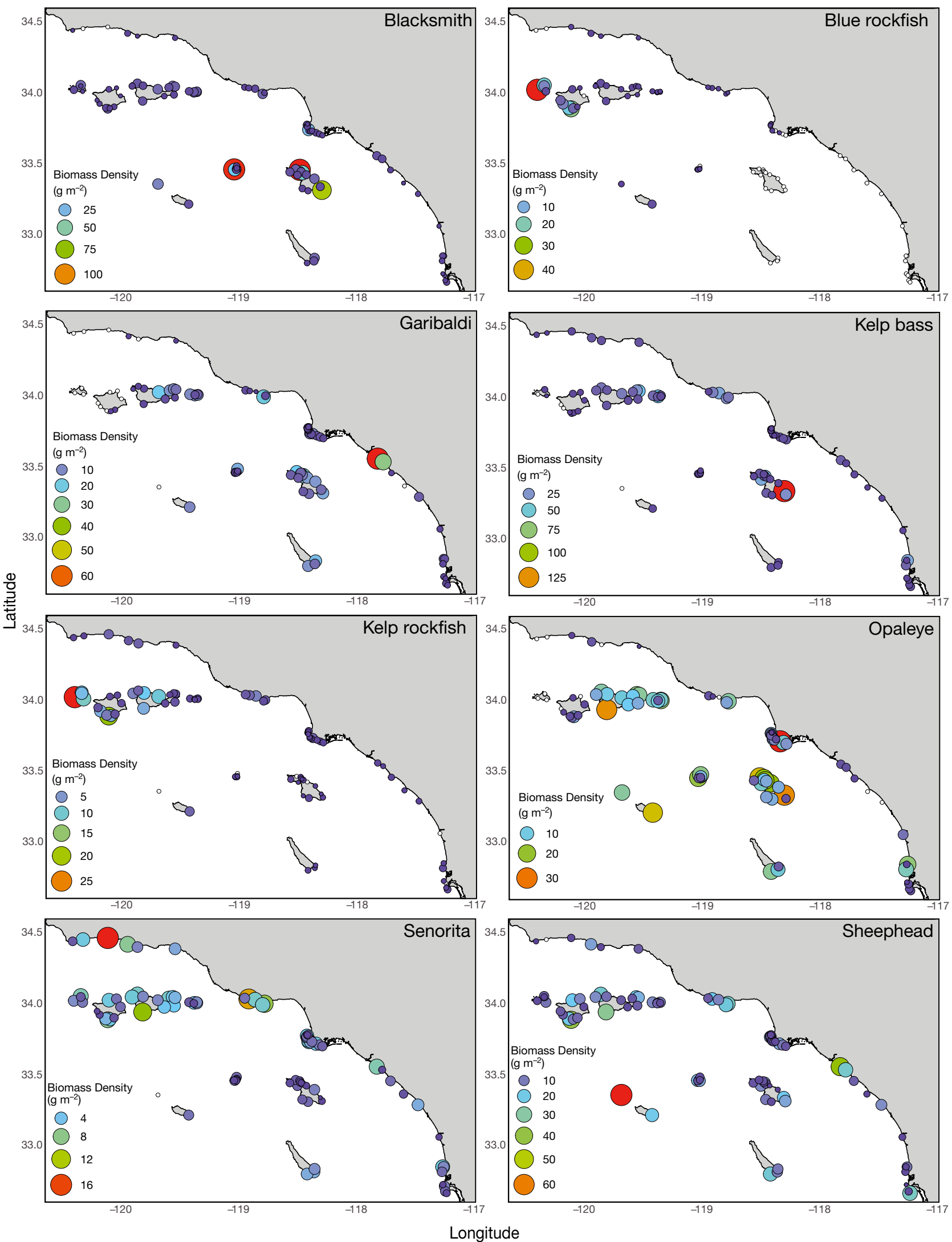

Fig. 5. Heat map of biomass density $\left(\mathrm{g} \mathrm{m}^{-2}\right)$ of the focal fish species at the study reef sites in the SCB; empty circles are zeros 
than SST and CHL, which both measure conditions at the surface. Since this region is highly stratified, DIST appears to be a proxy for temperature and upwelling below the thermocline. Reef slope was positively correlated with biomass density uniformly across the top models in which it occurred. These strong correlations with increasing reef slope, along with high variability in relief (as quantified by RISD) and proximity to the shelf break, suggest that habitat heterogeneity, not simply a particular relief, is important in driving high fish biomass on temperate rocky reefs in southern California. Habitat heterogeneity has been demonstrated to influence fish biomass or density in temperate rocky reef communities in the Mediterranean Sea (García-Charton et al. 2004), tropical reefs in the Cook Islands and Hawaii (Friedlander \& Parrish 1998, Miller et al. 2012), and in deepwater rockfish species in central California (Wedding \& Yoklavich 2015). Together this suggests that physical reef characteristics plus localized and regional forcing parameters drive the patterns of fish biomass in the SCB.

Historically, estimates of reef fish biomass density have been sparsely reported. As non-extractive techniques have evolved and been refined, recent estimates of reef fish biomass density in various locales vary appreciably. On average, we report a biomass density of $71.1 \mathrm{~g} \mathrm{~m}^{-2}$ with a range of 8.0 to $219.5 \mathrm{~g} \mathrm{~m}^{-2}$ (see Table S1) across 89 reefs in the SCB. At isolated unfished Pacific Atolls, coral reef fish biomass density ranged from 260 to $800 \mathrm{~g} \mathrm{~m}^{-2}$, while fished atolls had predictably lower biomass (130-170 $\mathrm{g} \mathrm{m}^{-2}$; Sandin et al. 2008). A larger-scale study of coral reef fish biomass at Pacific islands and atolls that span wide levels of human impact observed reef fish biomass densities that ranged from 8.3 to $129.6 \mathrm{~g} \mathrm{~m}^{-2}$ (Williams et al. 2015). Kelp forest fish biomass values in the Tristan da Cunha Islands, an isolated volcanic archipelago in the south Atlantic with low levels of extraction, varied from 150 to $275 \mathrm{~g} \mathrm{~m}^{-2}$ and were comparable (average $=230 \mathrm{~g} \mathrm{~m}^{-2}$ ) to those observed in remote oceanic islands with similar fishing pressure off Chile (Friedlander et al. 2014, Caselle et al. 2018b). On average, oil-platform fish biomass density from southern California was $514.8 \mathrm{~g} \mathrm{~m}^{-2}$ as these platforms had the highest studied fish production in the world (Claisse et al. 2014). Previous estimates for kelp bed fishes in the SCB and the Pacific Coast of Baja California Mexico were 33.2 to $37.5 \mathrm{~g} \mathrm{~m}^{-2}$ (Quast 1968), $22 \mathrm{~g} \mathrm{~m}^{-2}$ across the Bight (Ambrose and Swarbrick 1989) and an average of $121 \mathrm{~g} \mathrm{~m}^{-2}$ across the northern Channel Islands in southern California (Caselle et al. 2015). The latter reported a maximum of $270 \mathrm{~g} \mathrm{~m}^{-2}$ in a $10 \mathrm{yr}$ old marine reserve in the Channel Islands (protected for $>10 \mathrm{yr}$ ), which was not included in our study. All reefs, with the exception of MPAs, in southern California are intensively fished, and the scale at which these landings are reported (10 nautical mile blocks) makes comparisons among reefs difficult as a single block may incorporate multiple reefs (Zellmer et al. 2018). Thus, it is not surprising that HII was not a significant factor in the top models for total fish biomass or the individual species. Our results are consistent with fished reef habitats throughout the world, especially considering the removal of coastal pelagic species that skew biomass estimates appreciably upwards. For instance, large mobile predators were included in the Pacific Atoll study (Sandin et al. 2008), while we specifically excluded these coastal pelagic taxa from our analyses. More important than the comparison of techniques is the understanding of the source in variation among our biomass density estimates.

Individual reefs that maintain high biomass densities can do so for multiple reasons. Several may be acting as de facto reserves. For instance, Lover's Cove had the greatest biomass density (of all fishes combined) observed in this study and is a long-established tourist area immediately adjacent to Avalon, Santa Catalina Island. This reef is located within an MPA where fish are fed by tourists, is locally patrolled, has no reported extraction in our model, and has the highest kelp bass Paralabrax clathratus density observed in the study. Tyler Bight on San Miguel Island, while open to fishing, is a remote location and has high rockfish biomass densities, especially for blue rockfish Sebastes mystinus, the primary coldwater planktivore in this region. Similarly, the warmtemperate planktivorous blacksmith Chromis punctipinnis, a relatively unfished species, is the driver of high biomass at Santa Barbara Island - Sutil and Santa Catalina Island - East Quarry. High biomass densities of planktivores may be a result of the ecological release due to fishing down mesocarnivores, but these island reefs have high slope and relief and, while not tested, high tidal current velocities that may facilitate planktivore success due to the flux through the system.

The scale and complexity of the SCB are particularly challenging, and this study reports one of the most intensive field and quantitative assessments ever conducted. This ecosystem is proximate to one of the largest coastal population centers and economies in the world. As such, there is intense recreational and commercial fishing pressure and associated anthropogenic challenges (e.g. pollution, runoff, 
vessel traffic), and on a macroscale, standing stocks of fishes are reflective of these pressures. However, overall fish biomass on a per reef basis does not relate to these broad pressures, likely due to intense extraction throughout the system and reporting at a coarser scale than our study unit which incorporates multiple reefs in a reporting block (Zellmer et al. 2018). The scale of the study also subsumes smallerscale reef processes such as depth and kelp canopy perimeter. For instance, reefs with high slope tend to have planktivores concentrated on their edge when giant kelp is present, and this potentially concentrates their biomass within the $20 \mathrm{~m}$ isobath, the outer edge of our study unit. On reefs with low slope that have a deeper component, the edge of the canopy is potentially outside of our study unit, and the concentration of fishes feeding on its perimeter would not be included. The positive relationship between urchin density (UD) and blacksmith biomass may also reflect this situation, with higher urchin densities resulting in more sparse giant kelp and these planktivores being more well-distributed across the sampled area. Additionally, the positive relationship between urchin density and garibaldi biomass may be a result of a reduction in the shading effects of larger kelps, making these areas preferential for this damselfish species that has territorial males which maintain algal nests to attract females (Clarke 1970). Other reef characters in our region such as mean substrate (MSI) and mean vertical relief (MRI), previously shown to influence community structure, fish density, and biomass (Ambrose \& Swarbrick 1989), were not critical factors in this analysis; however, the variation in these factors was. The standard deviation of relief (RISD) was positively correlated with total fish biomass and biomass of 3 other species. This indicates that complex and variable reefs are more productive than homogenous ones. Complex habitats support more life history stages and provide more niches. Thus, investigating within-habitat variation and utilization may help determine the mechanisms that support biomass. At the scale of reefs studied here, variation in the biomass of marine fishes is due primarily to oceanographic forcing and geologic parameters. Indicators of high primary productivity and availability of cool nutrient-rich waters (demonstrated by SST, DIST, and CHL) link primary productivity to the maintenance of fish reef biomass density. Our findings are consistent with those of the rest of the Northeast Pacific (Ware \& Thomson 2005) and the tropical central Pacific (Williams et al. 2015). In the Northeast Pacific, forcing was primarily due to chl $a$ on large spatial scales (Ware \& Thomson 2005).
In the tropical Pacific, there was approximately double the biomass found on islands with the highest chl a values compared to those with the lowest chl a values; where, chl a was the primary forcing metric used. Along these lines, we have added a novel metric to studies of distributions, distance to the $200 \mathrm{~m}$ isobath (DIST). Based our observation that reefs closer to the $200 \mathrm{~m}$ isobath, the shelf break in our region, are regularly inundated with colder water below the thermocline, we hypothesize that this is an appropriate indirect remote-sensed metric for upwelling. This metric also has enhanced spatial resolution $\left(200 \mathrm{~m}^{2}\right)$ versus chl a $\left(1 \mathrm{~km}^{2}\right)$, and this may increase the ability to detect relationships on smaller spatial scales. This metric, coupled with traditional estimates of primary forcing and a novel method of estimating reef slope (SLOP), are important predictors for the maintenance of fish biomass density, and both can be relatively easily calculated and potentially applicable in other ecosystems. These biological surveys were conducted over a decade, and while the SCB is dynamic with respect to large-scale oceanographic process, especially El Niño-Southern Oscillation fluctuations, we note that there were no major El Niño events during this period. It is also important to note that the biomass estimates are consistent with fished reefs in highly productive ecosystems worldwide, demonstrating the potential applicability for this type of approach in other ecosystems.

\section{CONCLUSIONS}

We reported on general patterns of oceanographic forcing, geological characteristics and biological metrics that correspond with fish biomass density across a heterogeneous and dynamic temperate reef ecosystem using readily available metrics of potential drivers. Our analyses highlighted where improvements to future assessments may still be possible. A finer-scale assessment of harvest intensity than used here would not only allow evaluations of individual reef performance but would also contribute to evaluations of ongoing spatial management tools in the $\mathrm{SCB}$, such as marine protected areas. This region is generally considered an impaired water body due to runoff, sedimentation, aerial deposition and point source discharges. This heavily urbanized setting and associated infrastructure decouples pollution sources and watersheds from their corresponding input locations. At the reef scale, data do not exist to evaluate these localized effects, and many of these stressors will act on large spatial scales (Schaffner et 
al. 2014). It should be noted that both harvest intensity and some land-based pollution impacts are likely to shift locations over time, making assessment of their impact challenging. Nonetheless, certain areas of the SCB support higher fish biomass densities, a critical factor for secondary production, and the corresponding physical and biological metrics (many of which will remain stable over time) are informative. This information can inform future reef restoration of degraded habitats, the potential construction of manmade reefs (Zellmer et al. 2019), fishery management actions, and marine protected area evaluations. Knowing what areas of the coastline are more productive can help in prioritizing such projects and provide the appropriate context for their evaluation.

Acknowledgements. This study was funded by NOAA Saltonstall-Kennedy Grant \#NA15NMF4270320. We thank Matt Robart, Tom Bell, Stephen Gosnell, Kyle Cavanaugh, Milton Love, Laurel Zahn, Oxy undergraduate student researchers, Tom Ford, Brian Meux, Shauna Oh, Bill Power, Dave Witting, Katie Davis, Avery Parsons-Field, Peter Carlson, Ken Schiff, Mary Bergen, Jessica Bredvik, Phyllis Grifman, PISCO divers and the following agencies: Ocean Protection Council, California SeaGrant, the David and Lucille Packard Foundation in support of the Partnership for Interdisciplinary Studies of Coastal Oceans (PISCO), the Santa Monica Bay Restoration Commission, the Bay Foundation, Montrose Settlements Restoration Program, US Navy and USC Seagrant including a graduate traineeship to C.M.W.

\section{LITERATURE CITED}

Allen LG, Pondella DJ II (2006) Ecological classification. In: Allen LG, Pondella DJ II, Horn M (eds) The ecology of marine fishes: California and adjacent waters. University of California Press, Los Angeles, CA, p 149-166

Ambrose RF, Swarbrick SL (1989) Comparison of fish assemblages on artificial and natural reefs off the coast of southern California. Bull Mar Sci 44:718-733

Anderson TW, DeMartini E, Roberts DA (1989) The relationship between habitat structure, body size and distribution of fishes at a temperate artificial reef. Bull Mar Sci 44:681-697

Arnold TW (2010) Uninformative parameters and model selection using Akaike's information criterion. J Wildl Manag 74:1175-1178

Atwater TM (1998) Plate tectonic history of southern California with emphasis on the western transverse ranges and Northern Channel Islands. In: Weigand PW (ed) Contributions to the geology of the Northern Channel Islands, southern California, Book MP 45. American Association of Petroleum Geologists, Pacific Section, Ventura, CA, p 1-8

Ban SS, Alidina HM, Okey TA, Gregg RM, Ban NC (2016) Identifying potential marine climate change refugia: a case study in Canada's Pacific marine ecosystems. Glob Ecol Conserv 8:41-54

Begueria S, Pueyo Y (2009) A comparison of simultaneous autoregressive and generalized least squares models for dealing with spatial autocorrelation. Glob Ecol Biogeogr
18:273-279

* Behrens MD, Lafferty KD (2007) Temperature and diet effects on omnivorous fish performance: implications for the latitudinal diversity gradient in herbivorous fishes. Can J Fish Aquat Sci 64:867-873

* Bell TW, Cavanaugh KC, Reed DC, Siegel DA (2015) Geographical variability in the controls of giant kelp biomass dynamics. J Biogeogr 42:2010-2021

Bell TW, Cavanaugh KC, Siegel DA (2017) Time series of quarterly NetCDF files of kelp biomass in the canopy from Landsat 5, 7, and 8, 1984-2016 (ongoing). Santa Barbara Coastal LTER Marine Science Institute, University of California Santa Barbara, CA

* Bodkin JL (1988) Effects of kelp forest removal on associated fish assemblages in central California. J Exp Mar Biol Ecol 117:227-238

* Borer ET, Seabloom EW, Shurin JB, Anderson KE and others (2005) What determines the strength of a trophic cascade? Ecology 86:528-537

Burnham K, Anderson D (2002) Model selection and multimodel inference: a practical information-theoretic approach. Springer, New York, NY

Caselle JE, Hamilton SL, Schroeder DM, Love MS, Standish JD, Rosales-Casian JA, Sosa-Nishizaki O (2011) Geographic variation in density, demography, and life history traits of a harvested, sex-changing, temperate reef fish. Can J Fish Aquat Sci 68:288-303

Caselle JE, Rassweiler A, Hamilton SL, Warner RR (2015) Recovery trajectories of kelp forest animals are rapid yet spatially variable across a network of temperate marine protected areas. Sci Rep 5:14102

* Caselle JE, Davis K, Marks LM (2018a) Marine management affects the invasion success of a non-native species in a temperate reef system in California, USA. Ecol Lett 21: 43-53

Caselle JE, Hamilton SL, Davis K, Turchik A, Jenkinson R, Simpson D, Sala E (2018b) First quantification of subtidal community structure at Tristan da Cunha islands in the remote South Atlantic: from kelp forests to the deep sea. PLOS ONE 13:e0195167

* Cavanaugh KC, Siegel DA, Reed DC, Dennison PE (2011) Environmental controls of giant-kelp biomass in the Santa Barbara Channel, California. Mar Ecol Prog Ser 429:1-17

Claisse JT, Pondella DJ II, Williams JP, Sadd J (2012) Using GIS mapping of the extent of nearshore rocky reefs to estimate the abundance and reproductive output of important fishery species. PLOS ONE 7:e30290

Claisse JT, Pondella DJ II, Love M, Zahn LA, Williams CM, Williams JP, Bull AS (2014) Oil platforms off California are among the most productive marine fish habitats globally. Proc Natl Acad Sci USA 111:15462-15467

* Claisse JT, Pondella DJ II, Love M, Zahn LA, Williams CM, Bull AS (2015) Impacts from partial removal of decommissioned oil and gas platforms on fish biomass and production on the remaining platform structure and surrounding shell mounds. PLOS ONE 10:e0135812

Claisse JT, Blanchette CA, Dugan JE, Williams JP and others (2018) Biogeographic patterns of communities across multiple marine ecosystems in southern California. Mar Ecol 39:e12453

Clarke TA (1970) Territorial behavior and population dynamics of a pomocentrid fish, the garibaldi, Hysypops rubicunda. Ecol Monogr 40:189-212

* Clarke GL, Edmondson WT, Ricker WE (1946) Mathematical formulation of biological productivity. Ecol Monogr 16: 
321-337

Connell SD, Jones GP (1991) The influence of habitat complexity on postrecruitment processes in a temperate reef fish. J Exp Mar Biol Ecol 151:271-294

Conover DO, Present TMC (1990) Countergradient variation in growth rate: compensation for length of the growing season among Atlantic silversides from different latitudes. Oecologia 83:316-324

Cushing DH (1975) Marine ecology and fisheries. Cambridge University Press, Cambridge

DeLong JP, Gilbert B, Shurin JB, Savage VM and others (2015) The body size dependence of trophic cascades. Am Nat 185:354-366

* Dulvy NK, Freckleton RP, Polunin NVC (2004) Coral reef cascades and the indirect effects of predator removal by exploitation. Ecol Lett 7:410-416

Ebeling AW, Larson RJ, Alevizon WS (1980) Habitat groups and island-mainland distribution of kelp-bed fishes off Santa Barbara, California. In: Powers DM (ed) The California Islands, proceedings of a multidisciplinary symposium. Santa Barbara Museum of Natural History, Santa Barbara, CA, p 403-431

Emery KO (1960) The sea off southern California. John Wiley \& Sons, New York, NY

Engle JM (1993) Distribution patterns of rocky subtidal fishes around the California Islands. Third California Islands Symposium, Santa Barbara, CA

ESRI (2014) ArcGis Desktop: release 10.3. Environmental Systems Research Institute, Redlands, CA

Eurich JG, Selden RL, Warner RR (2014) California spiny lobster preference for urchins from kelp forests: implications for urchin barren persistence. Mar Ecol Prog Ser 498:217-225

Fonseca VP, Pennino MG, de Nobrega MF, Oliveira JEL, Mendes LdF (2017) Identifying fish diversity hot-spots in data-poor situations. Mar Environ Res 129:365-373

Foster MS, Schiel DR (2010) Loss of predators and the collapse of southern California kelp forests (?): alternatives, explanations and generalizations. J Exp Mar Biol Ecol 393:59-70

Friedlander AM, Parrish JD (1998) Habitat characteristics affecting fish assemblages on a Hawaiian coral reef. J Exp Mar Biol Ecol 224:1-30

Friedlander AM, Ballesteros E, Fay M, Sala E (2014) Marine communities on oil platforms in Gabon, West Africa: high biodiversity oases in a low biodiversity environment. PLOS ONE 9:e103709

* García-Charton JA, Pérez-Ruzafa A, Sánchez-Jerez P, Bayle-Sempere JT, Reñones O, Moreno D (2004) Multiscale spatial heterogeneity, habitat structure, and the effect of marine reserves on Western Mediterranean rocky reef fish assemblages. Mar Biol 144:161-182

Graham MH (2004) Effects of local deforestation on the diversity and structure of southern California giant kelp forest food webs. Ecosystems 7:341-357

Hamilton SL, Caselle JE, Malone DP, Carr MH (2010) Incorporating biogeography into evaluations of the Channel Islands marine reserve network. Proc Natl Acad Sci USA 107:18272-18277

*Harrold C, Reed DC (1985) Food availability, sea urchin grazing, and kelp forest community structure. Ecology 66:1160-1169

Hickey BM (1992) Circulation over the Santa-Monica SanPedro Basin and shelf. Prog Oceanogr 30:37-115

Hickey BM (1993) Physical oceanography. In: Dailey MD,
Reisch DJ, Anderson JW (eds) Ecology of the Southern California Bight. University of California Press, Berkeley, CA, p 19-70

*Hixon MA, Beets JP (1993) Predation, prey refuges, and the structure of coral-reef fish assemblages. Ecol Monogr 63: $77-101$

Hubbs CL (1948) Changes in the fish fauna of western North America correlated with changes in ocean temperature. J Mar Res 7:459-482

Jackson JBC, Kirby MX, Berger WH, Bjorndal KA and others (2001) Historical overfishing and the recent collapse of coastal ecosystems. Science 293:629-637

Johnson JB, Omland KS (2004) Model selection in ecology and evolution. Trends Ecol Evol 19:101-108

Kamykowski D (1987) A preliminary biophysical model of the relationship between temperature and plant nutrients in the upper ocean. Deep Sea Res A 34:1067-1079

Kennelly SJ (1989) Effects of kelp canopies on understorey species due to shade and scour. Mar Ecol Prog Ser 50: 215-224

Konotchick T, Parnell PE, Dayton PK, Leichter JJ (2012) Vertical distribution of Macrocystis pyrifera nutrient exposure in southern California. Estuar Coast Shelf Sci 106:85-92

* Ling SD, Johnson CR, Frusher SD, Ridgway KR (2009) Overfishing reduces resilience of kelp beds to climate-driven catastrophic phase shift. Proc Natl Acad Sci USA 106: 22341-22345

Ling SD, Scheibling RE, Rassweiler A, Johnson CR and others (2015) Global regime shift dynamics of catastrophic sea urchin overgrazing. Philos Trans R Soc Lond B Biol Sci 370:2013.0269

Miller EF, Beck DS, Dossett W (2008) Length-weight relationships of select common nearshore southern California marine fishes. Bull South Calif Acad Sci 107:183-186

*Miller SL, Shima JS, Phillips NE (2012) Effects of microhabitat availability on estimates of density of a reef fish: implications for assessments of marine protected areas. Hydrobiologia 685:173-190

*Miller RJ, Lafferty KD, Lamy T, Kui L, Rassweiler A, Reed DC (2018) Giant kelp, Macrocystis pyrifera, increases faunal diversity through physical engineering. Proc R Soc Lond B Biol Sci 285:2571

Oliver ECJ, Donat MG, Burrows MT, Moore PJ and others (2018) Longer and more frequent marine heatwaves over the past century. Nat Commun 9:1324

*Parnell PE (2015) The effects of seascape pattern on algal patch structure, sea urchin barrens, and ecological processes. J Exp Mar Biol Ecol 465:64-76

Patsch K, Griggs G (2006) Littoral cells, sand budgets, and beaches: understanding California's shoreline. California Coastal Sediment Management Workgroup, University of California, Santa Cruz, CA

* Perry AL, Low PJ, Ellis JR, Reynolds JD (2005) Climate change and distribution shifts in marine fishes. Science 308:1912-1915

Pondella DJ, Allen LG (2000) The nearshore fish assemblage of Santa Catalina Island. In: Browne DR, Mitchell KL, Chaney HW (ed) The Proceedings of the Fifth California Islands Symposium. Santa Barbara Museum of Natural History, Santa Barbara, CA, p 394-400

* Pondella DJ II, Gintert BE, Cobb JR, Allen LG (2005) Biogeography of the nearshore rocky-reef fishes at the southern and Baja California islands. J Biogeogr 32: 187-201

Pondella DJ II, Williams JP, Claisse JT, Schaffner R, Ritter K, 
Schiff K (2015a) The physical characteristics of nearshore rocky reefs in the Southern California Bight. Bull South Calif Acad Sci 114:105-122

Pondella DJ II, Zahn LA, Love MS, Siegel D, Bernstein BB (2015b) Modeling fish production for southern California's petroleum platforms. Integr Environ Assess Manag 11:584-593

Quast JC (1968) Estimates of the populations and the standing crop of fishes. In: North WJ, Hubbs CL (eds) Utilization of kelp-bed resources in Southern California. Fish Bull 139:57-79

R Development Core Team (2018) R: a language and environment for statistical computing. R Foundation for Statistical Computing, Vienna. https://cran.r-project.org

Reed DC, Foster MS (1984) The effects of canopy shading on algal recruitment and growth in a giant kelp (Macrocystis pyrifera) forest. Ecology 65:937-948

Reed DC, Rassweiler A, Carr MH, Cavanaugh KC, Malone DP, Siegel DA (2011) Wave disturbance overwhelms topdown and bottom-up control of primary production in California kelp forests. Ecology 92:2108-2116

Roberts CM, Ormond RFG (1987) Habitat complexity and coral reef fish diversity and abundance on Red Sea fringing reefs. Mar Ecol Prog Ser 41:1-8

Sandin SA, Smith JE, DeMartini EE, Dinsdale EA and others (2008) Baselines and degradation of coral reefs in the northern Line Islands. PLOS ONE 3:e1548

Schaffner RA, Steinberg SJ, Schiff KC (2014) A GIS tool to compute a pollutant exposure index for the Southern California Bight. In: Wright DJ (ed) Ocean solutions earth solutions. Esri Press, Redlands, CA, p 109-133

Sea Around Us Project (2012) http://www.seaaroundus.org/ data

Selden RL, Gaines SD, Hamilton SL, Warner RR (2017) Protection of large predators in a marine reserve alters size-dependent prey mortality. Proc Biol Sci 284: 20161936

Stamoulis KA, Delevaux JMS, Williams ID, Poti M and others (2018) Seascape models reveal places to focus coastal fisheries management. Ecol Appl 28:910-925

Steneck RS, Graham MH, Bourque BJ, Corbett D, Erlandson JM, Estes JA, Tegner MJ (2002) Kelp forest ecosystems: biodiversity, stability, resilience and future. Environ Conserv 29:436-459

Editorial responsibility: Jana Davis, Annapolis, Maryland, USA
Stephens JS, Larson R, Pondella DJ II (2006) Rocky reefs and kelp beds. In: Allen LG, Pondella DJ II, Horn M (eds) Ecology of marine fishes: California and adjacent waters. University of California Press, Los Angeles, CA, p 227-252

Tam JC, Link JS, Rossberg AG, Rogers SI and others (2017) Towards ecosystem-based management: identifying operational food-web indicators for marine ecosystems. ICES J Mar Sci 74:2040-2052

* Tegner MJ, Dayton PK (2000) Ecosystem effects of fishing in kelp forest communities. ICES J Mar Sci 57:579-589

Vanney JR, Stanley DJ (1983) Shelfbreak physiography: an overview. In: Stanley DJ, Moore GT (eds) The shelfbreak: critical interface on continental margins. SEPM (Society for Sedimentary Geology), Tulsa, OK, p 1-24

WWare DM, Thomson RE (2005) Bottom-up ecosystem trophic dynamics determine fish production in the northeast Pacific. Science 208:1280-1284

Wedding L, Yoklavich MM (2015) Habitat-based predictive mapping of rockfish density and biomass off the central California coast. Mar Ecol Prog Ser 540:235-250

Williams CM, Williams JP, Claisse JT, Pondella DJ II, Domeier ML, Zahn LA (2013) Morphometric relationships of marine fishes common to central California and the Southern California Bight. Bull South Calif Acad Sci 113:217-227

*Williams ID, Baum JK, Heenan A, Hanson KM, Nadon MO, Brainard RE (2015) Human, oceanographic and habitat drivers of central and western Pacific coral reef fish assemblages. PLOS ONE 10:e0120516

WWorm B, Barbier EB, Beaumont N, Duffy JE and others (2006) Impacts of biodiversity loss on ocean ecosystem services. Science 314:787-790

Zellmer AJ, Claisse JT, Williams CM, Pondella DJ II (2018) Long-term, spatial marine harvest intensity as an indicator of human impact on shallow rocky reef ecosystems. Mar Ecol 39:e12463

Kellmer AJ, Claisse JT, Williams CM, Schwab S, Pondella DJ II (2019) Predicting optimal sites for ecosystem restoration using stacked-species distribution modeling. Front Mar Sci 6:3

Zuur AF, Ieno EN, Saveliev AA (2017) Spatial, temporal and spatial-temporal ecological data analysis with R-INLA. Highland Statistics, Newburgh

Submitted: March 21, 2019; Accepted: August 14, 2019

Proofs received from author(s): October 8, 2019 